\title{
Türkiye Türkçesinde mana birleşmesi problemi: “Gaye”, “Hedef”, "Maksat”, “Amaç" örneği
}

\section{Yasin YAYLA1}

\begin{abstract}
APA: Yayla, Y. (2020). Türkiye Türkçesinde mana birleşmesi problemi: "Gaye", "Hedef", "Maksat", "Amaç" örneği. RumeliDE Dil ve Edebiyat Araştırmaları Dergisi, (20), 145-156. DOI: $10.29000 /$ rumelide.791112.
\end{abstract}

\section{$\ddot{O} \mathbf{z}$}

Anlamdaşlı̆̆ın var olup olamayacağı ile ilgili birçok çalışma yapılmıştır. Bu çalışmaların çoğu, meselenin teorik kısmıyla ilgilidir. Konu hakkındaki çalışmaların ekseriyeti bir dilde tamamen aynı anlama gelen kelimelerin olamayacağı tezini savunmaktadır. Bu çalışmada da "anlamdaşlık”ın var olamayacağı ancak yakın anlamlılı̆̆ın var olabileceği kabul edilmiş ve çalışma bu kabul üzerine inşa edilmiştir. Osmanlı Türkçesinden Türkiye Türkçesine geçiş ile birlikte Türkiye Türkçesinde "yeni Türkçe kelimeler" olarak da isimlendirilen birçok yeni kelime ortaya çıkmıştır. Bu kelimelerin dile dahliyle birlikte, yakın anlamlı olan ve mana farkları bilinerek yerli yerinde kullanılan birçok kelimenin farklı manaları tek kelimeye yüklenip birçok mana tek kelime ile karşılanmağa çalışılmaktadır. Bu problemin gerek sözlü olarak konuşma Türkçesinde gerekse yazılı olarak sözlüklerde yansımaları mevcuttur. Bu çalışmada, mezkûr mana birleşmesi problemi Türkiye Türkçesi genelinde ve TDK Türkçe Sözlük özelinde "gaye”, "hedef” ve "maksat” kelimelerinin "amaç" kelimesinde birleşmesi örneği ile izah edilmiştir. Çalışmada önce üç kelimenin kendisinde birleştiği "amaç" kelimesi üzerinde durulduktan sonra sırasıyla "gaye", "hedef" ve "maksat" kelimelerinin etimolojileri, Osmanlı Türkçesindeki manaları, Türkçe Sözlük’teki manaları ve hem Osmanl Türkçesinde hem de Türkiye Türkçesindeki kullanılış örnekleri verilerek kelimelerin mana farkları izah edilmiştir.

Anahtar kelimeler: Anlamdaşlık, yakın anlamlılık, mana birleşmesi, mana farkı, Türkiye Türkçesi

\section{Semantic merging problem in Turkish: The example of "Gaye", "Hedef”, "Maksat", "Amaç"}

\begin{abstract}
There have been many studies as to whether or not synonymy can exist. Most of these studies are concerned with the theoretical part of the issue. The bulk of these studies on the subject advocate the thesis that words cannot have the same meaning in a language. In this study, it was acknowledged that not true synonymy but rather near-synonymy does exist. With the transition from Ottoman Turkish to modern Turkish many new words have emerged in Turkish, also known as "new Turkish words". With the adoption of these words into the language, the meaning differences of many nearsynonymy words have disappeared. Many different meanings are merged into one word. This is the case both in speech and in the writing language. In this study, the problem of meaning unification is illustrated by using the word "amaç" instead of "gaye", "hedef" and "maksat". In this study, firstly, the word "amaç" in which the latter words have been combined is emphasized. Then the etymology of the words "gaye", "hedef" and "maksat", meaning in Ottoman Turkish and TDK Turkish Dictionary are

1 Dr. Öğr. Üyesi, Kırklareli Üniversitesi, Fen Edebiyat Fakültesi, Türk Dili ve Edebiyatı Bölümü (Kırklareli, Türkiye), yyasinyayla@gmail.com, ORCID ID: 00oo-0001-5726-884X [Makale kayıt tarihi: 01.08.2020-kabul tarihi: 20.09.2020; DOI: $10.29000 /$ rumelide.791112]
\end{abstract}


examined. After that, example sentences are given from Ottoman Turkish and modern Turkish to better illustrate the case.

Keywords: Synonymy, near-synonym, semantic merging, meaning difference, Turkish

\section{Giriş}

Bir lisan içindeki mefhum değişmelerinin, bunun yansıttığı hayat tarzındaki değiş̧ikliklere paralel olarak seyrettiğini kabul edebiliriz. Araştırıcı ve öğrenen bir cemiyetten öğrenmek ve düşünmek istemeyen bir toplum hâline geçiş sürecinin, o toplumun mefhum sistemindeki değişmelerde nassl yansımasını bulduğu gerçekten araştırmaya değer bir konudur (Kocabaş, 2015: 12). Yok olan mefhumlar ile birlikte cemiyetten nelerin yok olduğu üzerine, sosyologlar ile filologların yapacağı ortak çalışmalarla kayda değer neticeler elde edileceği muhakkaktır.

Bu değişmenin sosyoloji ilmi ile birlikte araştırılması gereken ayağı dışında bir de cari hayatımızdaki yansımaları mevcuttur. Cemiyet hayatındaki bazı değişmelerin önüne geçilemez ve tabii akış içinde gerçekleşir. Bu değişmelerin kârları ve zararları ayrı bir tartışmanın ve ayrı bir disiplinin konusudur. Mesela günümüzde insanı bir yerden bir yere taşıma vazifesi gören otomobilin yerine eskiden at vardı ve toplumda at ile ilgili esas terimler yaygın bir şekilde kullanılıyor ve biliniyordu. Otomobilin yaygınlaşması ile birlikte "nal” yerini belki "marşpiyel”, "seyis"in yerini "oto tamircisi”, "tımar" $n$ yerini "cilalama”, "hara"nın yerini "garaj” almıştır. Makineli tarıma geçişle birlikte birçok kelime yok olmuştur; çünkü birçok aletin yapabileceği işi traktör tek başına yapabilmektedir. "Saban” kelimesi belli bir yaşın üstündeki insanların hafızasında bulunsa da artık kullanılmağa ihtiyaç duyulmamaktadır. Belli bir yaşın altındaki insanlar içinse sadece herhangi bir kitabın sayfalarında karşısına çıabilecek fakat zihninde müşahhas hâle getiremeyeceği bir kelime olarak kalmaktadır. Bu değişmeler bir aletin yerini başka bir alet almasıyla ya da bir kelimenin yerini başka bir kelime almasıyla olabileceği gibi aynı kelimenin uğradığı bir mana değişmesi ile de olabilir. Mesela "eski çamlar bardak oldu" atasözünde geçen "bardak" bugünkü su içtiğimiz cam bardak değil ağaçtan yapılan kovadır. Bardağın eskiden bu manada kullanıldığı bilindiğinde "bardaktan boşanırcasına yağmak" deyimi de anlaşlabilir. Eskiden "bardaktan boşanırcasına" dediğimiz yağmur şekline bugün "kovadan boşanırcasına" (Kaçalin, 2006: IX) diyemesek de böyle anlamamız gerekir. Bu değişmeler önü alınamaz değişmelerdir ve tabii bir seyirdir.

Bu tabii seyrin dışında gerçekleşen değişmeler de vardır. Bu çalışmanın problemini teşkil eden "mana birleşmesi” de böyle bir değişmenin neticesinde ortaya çıkmıştır.

\section{Mana birleșmesi ve yakın anlamlılık}

Farklı manaları muhtevi birden çok kelimenin, bu farklı manalarının tek kelimeye yüklenmesi ve birden çok kelime için tek kelimenin kullanılması ve hâliyle birden çok mananın tek kelimede birleşmesi "mana birleşmesi" diye isimlendirilebilir. Mana birleşmesi meselesi hususiyetle "yakın anlamlı" kelimeler arasında gerçekleşmiştir ve hâlâ da gerçekleşmektedir.

Her kelimenin bir ömrü, hafızası ve serüveni vardır (Duman, 2015: 23). Bu serüven boyunca kelimenin mana dünyası oluşur, şekillenir ve kelime, ifade etmek istenen mefhumu tam manasıyla karşılar. Yakın anlamlı kelimelerin arasındaki mana farkları yok olmaya başlayınca, birçok farklı mana tek kelime ile ifade edilmek istenince kelimelerin arasındaki incelikler yok olmağa başlar. Yakın anlamlı kelimeler; dilin kuvvetini, kudretini, kökenini, türe(t)me şekillerini ve kültür aktarıcılığını bünyesinde 
barındırmaktadır. Yakın anlamlı kelimelerin birini, ikisini, bazen üçünü beşini aynı kefeye koymak umut ve ümit arasındaki farkı bilemeyen bir insan kalabalığı doğurur (Duman, 2015: 23). Kelimelerin mana farklarının yok olması, gittikçe sayısı artmakta olan ve "anlamdaş" olarak isimlendirilen ve dil problemi olarak addedilebilecek bir kelimeler topluluğu ortaya çıkarmaktadır. Anlamdaşlığın var olup olmadığı üzerine birçok çalışma yapılmıştır. ${ }^{2}$ Çalışmaların ekseriyetinde bir dilde tamamen aynı manaya gelecek iki kelimenin var olamayacağı fikri savunulmuştur (Aksan, 1975: 531). Bu fikre karşı çlkan araştırmacıların ortaya sunduğu tezlerden birisi "gebe" "hamile" ve "eşek" "merkep" gibi kelimelerdir (Tekin, 1997: 113). Bu kelime ikililerinin birisi Türkçe ötekisi Arapçadır ve tam olarak birbiriyle aynı manaya geldiği iddia edilmektedir. Hâlbuki Tekin'in de dediği gibi buna dilbilimde "kaba ve hoş karşllanmayacak bir kelime veya deyimden kaçınma" manasında euphemism denmektedir ve her dilde örnekleri mevcuttur. (1997: 114). Mesela bir kişiye "merkep" diye değil "eşek" diye hakaret edilebilir. Ayrıca Arapçada hâmile 'taşıyıcı' merkeb ise 'gemi, vapur' manasına gelmektedir. Dil, hiçbir şekilde, aynı manaya gelen iki kelimeyi bir arada yaşatmamaktadır.

\section{Yeni kelimeler}

Türkçe için, "mana birleşmesi” meselesi yeni kelimelerin ortaya çıkması ile birlikte husule gelmiştir. Cumhuriyet'ten sonra belli bir tarihten itibaren ortaya çıan kelimelere yeni kelime denmektedir. Türkçede yeni kelimeler, türetme ya da birleştirme yoluyla yapılmıştır. Ayrıca Türkçenin daha önceki dönemlerinde kullanılmış, genellikle halk ağzında devam etmiş, yazı dilinde fazla rastlanmayan kelimelerin canlandırılmasıyla da yapılmıştır (Bayar, 2006: 7). Yeni kelimeler, 12 Mart 1933 yllında Türk Dili Tetkik Cemiyeti tarafından başlatılan ve üç buçuk ay boyunca devam eden anket ile de dile dâhil edilmiştir. Yeni kelime bulma çalışmalarına basın da dâhil olmuştur ve gazetelerdeki dil köşelerinde her gün on, on beş kelime verilerek anket çalışmaları yürütülmüş̧tür. Bu anket çalışmaları neticesinde dil uzmanı olmayan kişiler tarafından da teklif edilen kelimeler bulunması sebebiyle bazen bir Türkçe kelime birkaç yabancı kelimeye karşılık gösterilerek bir dil karmaşası oluşmasına sebebiyet verilmiştir. Daha sonra yazılı kaynakların da taranmasına karar verilmiş ve hem halk ağzından taranan hem de yazılı kaynaklardan taranan malzemeler 1934 yllında cemiyet tarafindan Osmanlıcadan Türkçeye Söz Karşıllkları Tarama Dergisinnde yayımlanmıştır (Bayar, 2016: 38). Bu derleme ve tarama çalışmalarının neticesinde tek bir yabancı kelime için birçok kelime ya da birçok yabancı kelime için tek bir kelime karşılığının teklif edilmesi, bir kavramın Anadolu ağızlarındaki karşılığının yanında çeşitli lehçelerdeki karşılıklarının da yer alması gibi birçok karışıklık ortaya çıkmıştır. Bunun neticesinde II. Türk Dili Kurultayında aşırılığı önleyecek tedbirler alınmış ve bir çalışma kolu oluşturulup 25 Mart 1935'te Osmanlıcadan Türkçeye Cep Kılavuzu ve 19 Temmuz 1935'te de Türkçeden Osmanlıcaya Cep Kılavuzu yayımlanmıştır (Bayar, 2016: 38). Bu kılavuzları esas alarak hazırladığı sözlüğünde Bayar, Türkçeden-Osmanlıcaya ve Osmanlıcadan-Türkçeye kelime dizini oluşturmuş (2006) ve Duman'ın "yakın anlamlı kelimelerin birini, ikisini, bazen üçünü beşini aynı kefeye koymak" (2015) ifadeleriyle tenkit ettiği meselenin bir nevi listesini sunmuştur.

Bugün, gerek konuşma dilinde gerekse, sözlüklerde yansımasını gördüğümüz, yazı dilinde mana birleşmesi örnekleri fazlasıyla mevcuttur. Mesela "zaruret” ve "mecburiyet" gibi farklı manalara sahip iki kelime "zorunluluk" kelimesinde birleşmiştir (TDK 2011: 2665). Hâlbuki “mecburiyet”"te bir şeyi zorla yapma, yaptırma durumu varken “zaruret” te ihtiyaç hissetme hâli mevcuttur. Bu iki farklı durumu ifade

\footnotetext{
2 Anlamdaşlı̆ı̆ var olamayacağını savunan şu çalışmalara bakılabilir: Ağakay M. A. (1956), Tekin T. (1997), Aksan D. (2004), Pilten Ş. (2013), Duman M. A. (2015), Sulak S. (2016). Anlamdaşlı ile ilgili görüşlerin ekseriyetini bir araya getiren şu çalışmaya da bakmak yerinde olacaktır: Akçataş A., Arı E. (2018).
} 
eden kelime "zorunluluk"3 kelimesi ile karşılanınca ifade edilmek istenen hâl anlaşılmaktan uzak kalmaktadır. "Öneri” kelimesinin sözlükteki karşıllğı 'teklif' iken (TDK 2011: 1853) “öner-” fiilinin karşılı̆̆ 'tavsiye et-, teklif et-'tir (TDK 2011: 1853). Birisine evlenmesini önerdiğimiz zaman ona acaba evlenme teklifinde mi bulunuyoruz yoksa evlenmesini mi tavsiye ediyoruz? Birbirinden tamamen farklı iki mefhum olan "teklif” ve "tavsiye”, “öneri” ve "öner-" kelimelerinin kullanılması ile birbirine karışmış durumdadır. Türkçe Sözlük’te "rüya” kelimesinin karşıllğı olarak verilen "düş” (TDK 2011: 1991) kelimesinden bir fiil türeyip "düşle-" (TDK 2011: 740) olunca 'hayal et-' fiili ile aynı manaya gelmektedir (TDK 2011: 1067). İçinde, yapılan işin zor olduğu manasını barındıran "itina" kelimesi ile yapılan işe ehemmiyet gösterme manasını barındıran "ihtimam" kelimesi “özen” kelimesinde birleşmiş (TDK 2011: 1867), böylelikle iki kelimenin mana farkı yok olmuştur.

Burada, Deniz vd.nin beyin sözlüğü (2019) adlı çalışmasını zikretmek yerinde olacaktır. Nöroloji ve mühendislik alanında yapılan bir çalışma olsa da mefhumların insan beynindeki yerleşme yerlerini ve hangi mantıkla yerleştiğini izah eden bir çalışma olduğu için yakın anlamlılık mevzuunda faydalanılabilecek bir çalışmadır. Çalışma İngilizce konuşan dokuz denek üzerinde yapılmıştır. Deneklere önce sesli kitap dinletip ardından da aynı kitabın basılı hâlini okutulmuş ve aynı anda denekler, MR cihazına bağlanıp deneklerin beyninin aktif olan bölgeleri belirlenmiştir. Araştırmaya göre aynı kavram alanına giren kelimeler insan beyninde yakın bölgelerde bulunmaktadır (2019: 7730). Söz gelimi “anne, baba, aile, eş, çocuk” kelimeleri beyinde aynı bölgede bulunmaktadır. Yine aynı araştırmada kelimelerin şekillerinin değil karşıladıkları mefhumların mühim olduğu, meselâ top kelimesinin karşıladığı farklı manaların beynin farklı bölgelerinde olduğu ifade edilmiştir (2019).

Yakın anlamlı kelimelerin karşıladığı farklı manaların beynin yakın bölgesinde olsa dahi aynı yerde olmadığı açıktır. Bu durumda, yakın anlamlı kelimelerin birinin ikisinin farklı manalarının dilden düşmesi, o mefhum ile karşllanmak istenen durumun da dilden düşerek artık karşılanamaz hâle gelmesine sebep olmaktadır. Bu durum insan düşüncesinde bir bulanıklık, boşluk oluşturduğu gibi Deniz vd.'nin yaptığı araştımaya göre insanın beyninde de fiziken bir boşluk oluşturmaktadır. Yakın anlamlı kelimelerinin mana farklarını bilip yerli yerinde kullanan bir insan ile bu kelimelerin mana farklarını bilmeden hepsinin yerine sadece tek kelime kullanan kişinin düşünce derinliği olarak aynı seviyede olmadığını söylemek mümkünken beyninin biyolojik olarak aynı durumda olmadığını da Deniz vd.'nin yaptı̆̆ı araştırma esas alınınca söylemek mümkündür.

Yakın anlamlı kelimeler arasında gerçekleşen söz konusu "mana birleşmesi” örneklerinden bir tanesi de "gaye", "hedef", "maksat” kelimelerinin "amaç" kelimesinde birleşmesidir. Bu çalışmada öncelikle "amaç" kelimesi incelenmiş ardından "amaç" kelimesinin yerini aldığı yakın anlamlı "gaye", "hedef", "maksat” kelimeleri üzerinde durulmuştur. Mana birleşmesi örneği için TDK Türkçe Sözlük kaynak alınmıştır. Söz konusu kelimelerin etimolojileri verilmiş, Osmanlı Türkçesinden günümüze kullanılış örnekleri gösterilmiş ve mana farkları ifade edilmiştir.

\section{Kelimeler}

\section{1. amaç}

TDK Türkçe Sözlük’te “amaç” kelimesinin karşılığı, kelimenin kullanılış örnekleri ile birlikte şu şekildedir:

3 “Zorunluluk” kelimesinde “+lI” ve “+lIk” ekleri anlaşılabilirken "zorun” kelimesi anlaşıllmaktan uzaktır. 
amaç, -cı $a$. 1. Ulaşılmak istenilen sonuç, maksat: "Evet ama öteki kızı bu iş için kaçırdılarsa amaçlarına ulaştılar." -Ahmet Ümit 2. Gaye: "Her milletten, her tabakadan, huyları, dinleri, dilleri farklı fakat amaçları aynı olan insanların bulunduğu bir yerdi burası." -İhsan Oktay Anar 3. Hedef: “Amaç, şüphe götürmeyecek ilk kesin bilgiye varmakt.." -İhsan Oktay Anar (TDK 2011: 110).4

Kelimelerin kullanılış örneklerine bakıldığında "amaç" kelimesinin "maksat, gaye ve hedef" kelimelerinin yerine kullanılabildiği görülmektedir; fakat bu kullanılışın söz konusu kelimelerin mana inceliklerini fark edilemez hâle getirdiği muhakkaktır. Örnek cümleler alt alta sıralanıp "amaç" yazan kısımlar boş bırakıldığında ve "gaye, maksat, hedef, amaç kelimelerini bu boşluklara yerleştirin" dendiğinde üniversite mezunu olan ya da olmayan insanların ekseriyetinin bilinçli bir şekilde boşlukları doğru dolduramayacağı muhakkaktır.

Bayar’ın Açıklamah Yeni Kelimeler Sözlüğü’nde Türk dili üzerine çalışmalar yapmakta olan ilim adamlarının yeni kelimeler hakkındaki görüşleri de bulunmaktadır. İlim adamlarının görüşlerini de içeren "amaç" kelimesi sözlükte şu şekildedir:

amaç (Farsça $\bar{a} m \bar{a} c$ ) [Eskiden beri kullanılan kelime dil devrimiyle canlandırılmıştır]: "gâye, hedef." T: Hedef, nişangâh. // D: Gaye, erek, hedef. // TOCK 1935: Hedef. // TDK 1945 -69: Ardından konuşulan, erişilmek istenilen sonuç. / 74-83: Erek, gâye, maksat./ 88-98: Erek, gaye, hedef. Ataç, Aksoy ve Özdemir amaçın dilimize girmiş yeni kelimelerden olduğunu ve yabancı karşllıklarının atılıp kullanılmaması gerektiğini söylemişlerdir. Timurtaş ve Hacıeminoğlu ise amaçın gâye, maksat, hedef karşılığı bulunan yanlış bir kelime olduğu, ayrıca menşeinin de belli olmadığı görüşündedir. Aksan, kelimenin Dîvânü Lugâti 't-Türk'te geçtiğini; ancak Farsçadan mı Türkçeye, Türkçeden mi Farsçaya geçtiğinin belli olmadığını, buna rağmen tutunmuş olduğunu


aldığını ifade etmiştir (2006: 34).

Kelimenin Türkiye Türkçesine dahliyle birlikte yaşanan tartışmalarda görüleceği üzere kelimenin kökeni hakkında kesin bir bilgi bulunmamaktadır. Ayrıca kelimenin "gaye, maksat, hedef" kelimelerinin yerine ikame edilen yanlış bir kelime olduğu ilim adamları tarafından da ifade edilmiştir; fakat bugün mezkûr üç kelime yerine kullanılmakta olan "amaç" kelimesinin netice itibarıly, Püsküllüoğlu'nun da dediği gibi, eleştirilse de Türkçedeki yerini aldığı muhakkaktır.

“Amaç” kelimesinin Türkçe Sözlük’teki karşllğı ve kelimenin Türkiye Türkçesindeki ortaya çıkış serüveninden sonra kelimenin kökenini ve manasını incelemek yerinde olacaktır. Kelime şu şekilde incelenebilir:

amaç: <Far. $\bar{a} m \bar{a} c$ 'Ok ve tüfek nişanesi nasb olunan toprak yığıntısı; nişâne-yi tîr; bir fersahın yirmi dörtte biri5 (Tebrîzî, 1251: 1, 176; Şu'ûrî, 1682: 1, 375; Şükûn, 1984: 75-76; Steingass, 1892: 97).

Farsça sözlüklere göre kökeni Farsça olan kelimenin Osmanlı Türkçesi sözlüklere göre de kökeni Farsçadır ve manası şu şekildedir:

\footnotetext{
$4 \quad$ Madde başının son manası şu şekilde idi: “4. Bir kimseye veya bir kurula verilen özel amaçlı görev, misyon.”. Fakat hem kullanılış örneği verilmediğinden hem de çalışmamızın muhteviyatını oluşturan kelimelerle ilgili olmadığından yukarıya alınmamıştır.

51 fersah, 3 mile eşittir yani yaklaşık 6 km.dir. (Hinz, 1990, 76). Bu durumda bir amaç yaklaşık 250 m.dir.
} 
amaç: < Far. 'Atıp vurmak üzere nişan alınacak şey, nişan tahtası' (İbrahim Cûdî Efendi, 2005: 14), 'hedef, ok ve tüfek atmaya dikilen nişan' (Redhouse, 2009, 20), 'Atılacak şey ile vurulmak üzere dikilen nişan, nişan tahtası' (Muallim Nâcî, 2009: 29), 'hedef üzerine ok ve kurşun atmak için dikilen tahta' (Toven, 2015: 24), 'amaç, ulaşllacak yer.' (Özön, 1965: 26).

Etimolojik sözlüklerde ise kelime şu şekildedir:

amaç: < ETü $\approx F a$.“ok nişanesi, hedef; saban demiri”, Türkçede ve Farsçada ortak olan sözcüğün, her iki dilde tatmin edici etimolojisi yoktur. Dil Devrimi döneminde, Türkçe kökenli olduğu varsayımıyla yeni anlam yüklenerek kullanımı teşvik edilmiştir (Nişanyan, 2018: 27); amac/amaç I/EO. omaç 'hedef' < J. Deny'ye göre Tk. J. Deny 1955 s. 214-219; fakat G. Doerfer 1965 II, no. 552 ve Clauson 1972 s. 156'ya göre bir İran dilinden 'saban' ve 'hedef' manalarında çok eski bir zamanda ET.'ye geçmiş bir kelime. amaç kelimesi aslen Türkçe olsun olmasın, bugünkü Türkçede birçok neologismusla beraber genç neslin dilinde yayılmakta ve hedef kelimesinin gittikçe kaybolmasına sebep olmaktadır. Bu amaçları gerçekleştirme kavgasına katılmağa çalışıyorum (F. Erdinç 1969 s. 5). Fa. Āmāèn bir manası 'bir fersengin yirmi dörtte biri’ idi, bu da Türkçenin bazı dalına ve bu meyanda EO.'ya da geçmiş (Tietze, 2002: 86).

Etimolojik sözlüklere göre kökeninin Farsça mı Türkçe mi olduğu tam manasıyla belli olmayan kelime hakkında Tietze'nin dedikleri dikkate şayandır. Tietze, 1969 yılında 'hedef' manasında kullanılmasına örnek verdiği "amaç" kelimesinin gençlerin dilinde yaygınlaştığını ve hedef kelimesinin kaybolmasına sebep olduğunu söylemektedir. Günümüzde ise Tietze'nin bahsettiği meselenin daha da ilerisine gidilerek amaç kelimesi hedef kelimesi ile birlikte gaye ve maksat kelimelerinin de yok olmasına sebebiyet vermektedir.

\section{2. gaye:}

Kelimenin kökeni şu şekildedir:

gaye: < Ar. $\dot{g} \bar{a} y a^{t}$ 'end, limit, goal, extremity, extreme' (Steingass, 1884: 744), 'nihayet ve encam; sancak' (Fîrûzâbâdî, 1272: 3, 894), 'nihayet, son, netice' (Atay vd., 1965: 245) < $\dot{g}-y$-y 'bayrağı yukarı çekmek, bayrak çekmek' (Atay vd., 1965: 245).

Kelimenin Osmanlı Türkçesi sözlüklerindeki manası şu şekildedir:

gayet: < Ar. 'Son, son derece': Mesâib gayetini buldu. Gâye suretinde de müstameldir. 'maksat, garaz, meram' manalarında da müstameldir: Gâye-yi hilkat marifetullahtur (İbrahim Cûdî Efendi, 2005: 136); 'Son, uç, nihayet, encam' (Redhouse, 2009: 112); 'Son, son derece': Galle-i nimet-i bî-gâyeti bilmez mikyâl. Gayet teşnegi. Bu manada "gaye" suretinde dahi kullanılır: Hamd-i bî-gâye (Muallim Nâcî, 2009: 170); gaye < Ar. 'Son, encam, afiyet; ecel, ahir, hadd, meda, nihaye, müntehi. Varılacak netice, hedef, maksat, matlup, murat, garaz, menvî, kasd, meram', gayet < T. (Arapçada $\dot{g} \bar{a} y \bar{a}^{t}$ şeklinde yazılır. Türkçede onun manası farklıdır. Bk. gaye.) 'Çok, ziyade, son derecede. Gayet büyük (Toven, 2015: 219); gaye 'Maksat; iş, sonuç 'ideal' karşıllı̆ı olarak (XIX. yy) (Özön, 1965: 225).

TDK Türkçe Sözlük'teki manası ise şu şekildedir:

gaye a. (ga:ye) Ar. $\dot{g} \bar{a} y e$ Elde edilmesi gereken, ulaşılmak istenen şey, amaç: "İnsanoğlunun gayesi ölmek değil, yaşamak ve galebe çalmaktır.” M. Kaplan (TDK, 2011: 906). 
Türkçe Sözlük'te "amaç” kelimesinin karşılıklarından biri olarak kullanılan "gaye” kelimesi Toven’in de dediği (2015: 219) gibi Arapçada غاية $\dot{g} \bar{a} y a^{t}$ şeklinde yazılırken 'çok, ziyade, son derece' manasına gelen "gayet” kelimesi ise غايت gàyat şeklinde yazılmaktadır. 'çok, ziyade, son derece' manasına gelen "gayet” kelimesinin Arapçadan Farsçaya geçerken yuvarlak "t"si düzleşmiş oradan da Türkçeye geçmiş ve böylece oluşmuş bir kelimedir6 (Tietze, 2009: 2, 107). Kelime Özön’ün de ifade ettiği üzere Osmanlı Türkçesinde 'ideal' manasında kullanılmağa başlanmıştır (1965: 225). Günümüz Türkçesinde kullanılıştan neredeyse düşmüş olan "gaye" kelimesinin karşıladığı mefhumun boşluğunu doldurmak için "amaç" dışında "nihai hedef" yapısının da kullanıldığını söylemek yerinde olacaktır. TDK Türkçe Sözlük'te kelimenin karşılığından "amaç" ile farkını anlamak mümkün değilken verilen örnekte 'ideal' manasının olduğu sezilmektedir.

Kelimenin Türkçedeki kullanılışına şu cümleler örnek gösterilebilir:

Öyle ki hayâtının hemen de tek gurûru ve gâyesi olan büyük servetini kardeşinin karşısında utanılacak bir ayıpmış gibi hissettiği zamanlar olur (Ayverdi ve Topaloğlu, 2008: 1021).

Onlar işportaya konan bir elma gibi onu süsleyip temizlemişler, parlatmışlar, sonra yağlı bir müşteriye okutmuşlardı. Kız yetiştirmekten de gaye bu değil miydi ya? (Tietze, 2009: 2, 107)

Hüsniye bana sade bir evlat ve bir torun değil bir gaye kazandırdı (Karay, 1957: 138).

Evet ben de belki paralı adam, gayesiz adam rolünden az çok bezdim, daha doğrusu zevk alamaz hâle geldim (Karay, 1957: 152)

Târîh-i beşeri dolduran bütün muharebeler, benliğini öldürmesini bilmeyen insanın bir gaye uğrunda ölmesini öğrenmesi için Cenab-ı Hakk’’n ona verdiği kanlı derslere benzer (Peyami Safa, 2000: 266)

Aramızda kaç kişi idrak eder, ki yeni bir millet olmaya çalıştığımız bu devrede gayeye varmak için tasarladığımız bütün terakki, temeddün, terbiye, irfan projeleri hep bu Türkçe meselesine dayanıyor (Beyatl, 1997: 84).

Kâinatın yüzü suyu hürmetine yaratıldı̆̆ gaye-insan ve ufuk peygamberin amcası Ebû Tâlib (Kısakürek, 1984: 10.).

Gayem: Dilimi, kalbimi, 28 yıllık mesleğimi ve idari müktesibatımı memleketimin, hemşehrilerimin, beni tanıyan ve tanımayan herkesin emir ve hizmetine sunmaktan ibarettir (Kürkçüoğlu, 114: 53)

Örneklerden de anlaşlacağı üzere "gaye" kelimesinin 'ideal, ülkü, ulaşılmak istenen uzak hedef' manaları mevcuttur. Bu kelimenin yerine "amaç" kelimesi kullanıldığında bu manaların farkedilmesi mümkün görünmemektedir.

\section{3. hedef:}

Kelimenin kökeni şu şekildedir:

\footnotetext{
6 “cennet” kelimesi de tıpkı "gâye” gibi Arapçada sonunda “yuvarlak t” bulunan bir kelimedir. Sonundaki “t”nin Türkçede telaffuz edilmesi Farsça üzerinden Türkçeye geçtiğinin bir delilidir (Kaçalin, M. S., 2003-2017). 
hedef: < Ar. hadaf'Mutlaka belend ve yüksek nesneye denür gerek bina ve gerek kum tepesi ve gerek dağ olsun. Ve ok nişanesine denür' (Fîrûzâbâdî, 1269: 2, 860), 'anything rising above the ground and visible from a distance; aim, target' (Steingass, 1884: 1168), < $h-d-f$ 'yaklaştırmak, yakın getirmek, yaklaşmak, yakın gelmek' (Atay vd., 1965: 329).

Kelimenin Osmanlı Türkçesi sözlüklerindeki manası şu şekildedir:

hedef: < Ar. hadaf'Nişangâh, amaç: Hedef-i tîr, hedef-i nigâh (İbrahim Cûdî Efendi, 2005: 172); 'Ok ve emsali atıp vurmak için dikilen nişan' (Redhouse, 2009: 141); 'Ok nişanesi, nişangâh. Maddiyat ve maneviyatta kullanılır: Hedef-i mermî, hedef-i garaz (Muallim Nâcî, 2009: 223); 'Nişan alınan nokta, tahta vesaire. Murat, meram, matlup, maksat, kast, garaz' (Toven, 2015, 268); 'Nişan noktası, amaç; mec. Varılmak istenen nokta, maksat, istek, niyet (Özön, 1965: 274); 'any prominent, erect object; a mark or target; a sight on any instrument' (Redhouse, 1890: 2160).

TDK Türkçe Sözlük'teki manası ise şu şekildedir:

hedef $a$. Ar. hedef 1. Nişan alınacak yer, nişangâh. 2. mec. Yapılması tasarlanan iş, amaç: "Asıl önemlisi devlet büyük hedefler dikmişti; milletin benimsediği, övündüğü hedeflerdi bunlar.”-T. Buğra. 3. Varılacak yer, ulaşılacak son nokta: "Ordular! İlk hedefiniz7 Akdeniz'dir. İleri!" -Atatürk (TDK, 2011: 1078).

Örneklerden de anlaşlacağı üzere "hedef" kelimesinin ilk manası 'ok ya da tüfek gibi silahlarla vurmak için dikilen nişan'dır, 'yapılması için tasarlanan iş' tarzındaki manalar mecazdır. Yukarıda "amaç" kelimesinin incelenmesinde de görüleceği üzere "amaç" kelimesi ancak "hedef" kelimesini karışlayabilmektedir. "Amaç" kelimesi incelenirken 'yaklaşık 250 m.yi karşılayan ok hedefi' manası ifade edilmişti. Fizikî olarak mesafenin yakınlığı mecaza da teşmil edilince gerek "hedef” kelimesinin gerekse "amaç" kelimesinin 'ülkü, ideal' gibi uzaklığı muhtevi bir manayı karşılaması mümkün görünmemektedir. Zaten sözlüklerde de kelimenin kullanılışına dair verilen örneklerde 'ülkü’yü belirten herhangi bir mana bulunmamaktadır.

Kelimenin Türkçedeki kullanılışına şu cümleler örnek gösterilebilir:

Zaten kadın makyajının asıl hedefi çehreye bu yarı buğu, serin ve taze çocuk tenini vermek değil mi? (Karay, 1957: 162)

Birden hız kazanan ateş gemisi doğruca hedefine ilerlemeye başladı (Tietze, 2009: 288).

Lâkin gûnâgûn hercümerçlere, muhaceretlere, istilâlara hedef olmuş, o saltanat sönmüş, o mazi hafâyâyı târîhe karışmış (Ünaydın, 1985: 199)

Tahsilde göz önünde bulundurulan hedefe ulaştırmak hususunda ilimlerin sıralarına riayet etmek gerektiği diğer bir şart olarak öne sürülüyor (Ayverdi ve Topaloğlu, 2008: 1254).

Hayat bir yarıştır ve hedefe herkesten önce varıştır. Hedef, Ekvator kuşağı uzunluğunda uzak olsa bile himmet küheylanına binenler için mesafe nihayet bir karıştır (Kürkçüoğlu, 100: 7).

'Ulaşılacak son nokta' manasına ilk hedef şeklinde verilen örneğin manayı karşılayan bir örnek olduğunu söylemek son derece/gayet güçtür. 
Örneklerden de anlaşılacağı üzere "hedef” kelimesi gerçek anlamında kullanıldığında manası açıkken mecaz anlamı ile kullanılınca 'varılmak istenen nokta' (Ayverdi ve Topaloğlu, 2008: 1254) manasını muhtevidir ve ulaşılacabilecek, sınırları belli bir istekten bahsedilmektedir.

\section{4. maksat:}

Kelimenin kökeni şu şekildedir:

maksat: < Ar. makssad 'intention, purpose, aim; wish, desire' (Steingass, 1884, 1042); 'plan, fikir' (Atay, 1965: 269) < k-ṣ-d 'bir nesneye teveccüh ve azm eylemek' (Fîrûzâbâdî, 1268: 1, 670); 'niyet etmek, kasd etmek, istemek, arzu etmek' (Atay, 1965: 269).

Kelimenin Osmanlı Türkçesi sözlüklerindeki manası şu şekildedir:

maksad: < Ar. maḳșad 'Kastolunan şey, meram, matlap' : Bir işten maksat ne ise hüküm ona göredir -Mecelle (İbrahim Efendi, 2005: 288); 'matlub ve meram olup kesb ü zafer ve vusulüne azim ve teveccüh olunan nesne' (Redhouse, 2009: 245); 'kasit, matlab, meram': Bu makaleyi yazmaktan maksadinız nedir? (Muallim Nâcî, 2009: 373); 'Kasdolunan şey, istenilen şey' Kendisini öldürmek maksadıyla mı aldı? (Özön, 1965: 426).

TDK Türkçe Sözlük'teki manası ise şu şekildedir:

maksat, -dı a. Ar. makșad İstenilen şey, amaç, gaye, erek: "Bugün oraya gitmeden evvel, Maarif idaresine uğradım. Maksadım evrakı geriye almaktı.”-R. N. Güntekin (TDK, 2011: 1612).

Kelimenin Türkçedeki kullanılışına şu cümleler örnek gösterilebilir:

Şemsi, ihtiyar Tatar'ın maksadını sezdi. Usulcacık cüzdanını çıardı; etrafındakilere fark ettirmeden bir beşlik kâğıt ayırıp elinin altından önüne sürdü (Karay, 1957: 20).

Bu sözündeki maksat da ayan (Tietze, 2018: 124)

Hekimlikten maksad âdem kurtarmak değil, hasta eyi etmekdir (Tietze, 2018: 124)

Maksadımız Galata hakkında kısa bir fikir vermektir (Ayverdi ve Topaloğlu, 2008: 1945).

Bu mukaddimeden maksadım, size karşı hissettiğim samimiyeti ifadedir. (Kürkçüoğlu, 114, 5)

Örneklerden de anlaşılacağı üzere "maksat” kelimesinde, kökeninde de mevcut olan, 'istemek, niyet etmek' manası bulunmaktadır.

\section{Sonuç ve teklifler}

Yakın anlamlı kelimelerin mana farklarının yok olması ve birkaç kelimenin tek kelimede birleşmesi "mana birleşmesi" diye isimlendirilebilir. Bu çalışmada, "gaye", "hedef" ve "maksat" kelimelerinin manalarının, Türkçe Sözlük’te de örneği görüldüğü üzere, "amaç” kelimesinde birleşmesi meselesine ve bu minvalde Türkçedeki mana birleşmesi problemine değinilmiştir. 
Çalışma neticesinde "gaye” kelimesinin 'ülkü, ideal, uzak umunç’ manalarında kullanılabileceği; "hedef" kelimesinin gerçek anlamı olan 'nişan alınacak yer' manası dışında mecaz olarak 'yapılması planlanan iş, varılmak istenen nokta' manalarında kullanıldığı ve "kısa vadeli, ulaşılması kısa vadede mümkün olan” bir işten bahsettiği; maksat kelimesinin ise kökeninde de mevcut olan 'istemek, niyet etmek' manasını muhtevi bir kelime olduğu anlaşılmıştır. "Amaç" kelimesinin ise Türkçe Sözlük'te de görüleceği üzere bu üç kelime yerine de kullanıldığı (2011:110); fakat kelimenin inceleme kısmında da görüleceği üzere ancak "hedef” kelimesine karşıllk olabileceği anlaşılmıştır. Tietze'nin "amaç kelimesi aslen Türkçe olsun olmasın, bugünkü Türkçede birçok neologismusla beraber genç neslin dilinde yayılmakta ve hedef kelimesinin gittikçe kaybolmasına sebep olmaktadı”" (2002: 86) sözleri ile tenkit ettiği "amaç" kelimesi bugün "hedef"in yerini almakla kalmayı "gaye" ve "maksat"ın yerini de almıştır.

Yakın anlamlı kelimelerin farklı manalarının kullanıştan düşmesi o mana ile karşılanmak istenen mefhumun da artık karşlanamaz olmasına sebebiyet vermektedir. Bu durum insan düşüncesinde bir bulanıklık, boşluk oluşturduğu gibi Deniz vd.'nin yaptığı araştımaya göre (2019) fiziken insanın beyninde de bir boşluk oluşturmaktadır. Meselâ "gaye", "hedef", "maksat" kelimelerinin mana farklarını bilip yerli yerinde kullanan bir insan ile bu kelimelerin mana farklarını bilmeden hepsinin yerine sadece "amaç" kelimesini kullanan kişinin düşünce derinliği olarak aynı seviyede olmadığını söylemek mümkünken beyninin biyolojik olarak aynı durumda olmadığını da, Deniz vd.'nin yaptığı araştırmaya göre, söylemek mümkündür. Bu durum, yabancı dilden Türkçeye ya da Türkçeden yabancı dile tercüme yaparken karşılanmak istenen mananın tam olarak karşılanamama sebeplerinin biyolojik olarak da izahı olabilir. Bu eksikliği aşmanın yolu, kelimelerin mana farklarını ifade eden ve bu farkların doğru kullanılış örneklerini de gösteren sözlüklerdir. Sözlükler, bir kelimenin manasını, karşılığına başka bir kelime koyarak -“amaç” kelimesinin karşılı̆̆ına 'maksat, gaye, hedef' (TDK, 2011: 110) koymak gibideğil o kelimeyi izah ederek vermelidir. Kullanıcı, bir kelimenin manası için sözlüğe baktığında o kelimenin hangi manaya geldiğini kelimenin cümle içinde kullanılış örneğine bakarak anlamağa çalışmamalı, kelimenin izahına bakarak anlayabilmelidir. Kelimelerin sözlüklerde de bulunamayan mana farklarının önce bulanıklaşıp sonra yok olacağı, bir sonraki adım olarak "bu kelimeler anlamdaş" denileceği, son adım olarak da "zaten anlamdaş, şunlara gerek yok" denilip daha az kullanılanlarının, sözlükten değilse bile, hem konuşma hem de yazı dilinden düşeceği muhakkaktır. Bu sebeple yakın anlamlı kelimeler üzerine çalışılması, bu kelimelerin mana farklarının izah edilmesi ve sözlüklere de kelimelerin bu mana farklarını izah eden tanımlarının ve örneklerinin konulması mühimdir ve gereklidir.

Bu minvalde, yaşayan Türkçenin kelimelerini muhtevi olması bakımından TDK Türkçe Sözlük'teki mana birleşmelerinin birer numunesi olan yakın anlamlı kelimelerin tespiti ve bu kelimelerin mana farklarını izah eden bir “Türkçe Yakın Anlamlı Kelimeler Sözlüğü” oluşturulması Türkçe için elzemdir.

\section{Kaynakça}

Ağakay, M. A. (1956). Türkçede Yakın Anlaml Kelimeler Sözlüğü. Ankara: Türk Tarih Kurumu Basımevi.

Akçaşat A. ve Arı, E. (2018). Anlambilimin Eş Anlamlılık Sorunu. Avrasya Dil Eğitim ve Araşttrmaları Dergisi, 2 (2), 60-84.

Aksan, D. (2004). Eşanlamlılık sorunu ve Türk yazı dilinin eskiliğinin saptanmasında eşanlamlılardan yararlanma. Dil Bilim ve Türkçe Yazıları. İstanbul: Multilingual.

Atay, H., Atay, İ. ve Atay M. (1965). Telaffuzlu Yeni Arapça-Türkçe Sözlük. Ankara.

Ayverdi, İ. ve Topaloğlu A. (2008). Astrlar boyu târihî seyri içinde Misalli Büyük Türkçe Sözlük. İstanbul: Kubbealtı. 
Bayar, N. (2006). Açıklamalı Yeni Kelimeler Sözlüğü. Ankara: Akçă̆.

Bayar. N. (2016). 1935 Cep Kılavuzlarında Yerlileştime Örnekleri, Bartın Üniversitesi Edebiyat Fakültesi Dergisi, 1 (1), 35-50.

Beyatl, Y. K. (1997). Edebiyata Dair. İstanbul: İstanbul Fetih Cemiyeti.

Deniz, F., Nunez-Elizade, A. O, Huth, A. G ve Gallant, J. L. (2019). The representatiton of semantic information across human cerebral cortex during listening versus reading is invariant to stimulus modality. The Journal of Neuroscience, 39, 7722-7736.

Duman, M. A. (2015). Dilde Belirsizlik ve Eş Anlamlılık. İstanbul: Litera.

Fîrûzâbâdî, M. (1268-1272). el-Ukyânûsu 'l-basît fí tercemeti 'l-kâmûsi 'l-muhît. Ahmed Âsım (Trc.). İstanbul: Matba'a-yı Bahriyye.

Hinz, W. (1990). İslâm’da Ölçü Sistemleri. A. Sevim (Çev.). İstanbul: Marmara Üniversitesi FenEdebiyat Fakültesi.

İbrahim Cûdî Efendi (2005). Lügat-i Cûdî. İsmail Parlatır, Belgin Tezcan Aksu, Nicolai Tufar (Haz.). Ankara: Türk Dil Kurumu.

Kaçalin, M. S. (2003-2017). Yayımlanmamış Ders Notları. İstanbul.

Kaçalin, M. S. (2006). Oğuzlarm Diliyle Dedem Korkudun Kitabı. İstanbul: Kitabevi.

Karay, R. H. (1957). Bu Bizim Hayatımız. İstanbul: İnkılâp Kitabevi.

Kısakürek, N. F. (1984). İlim Beldesinin Kapısı Hazret-i Ali. İstanbul: Büyük Doğu.

Kocabaş, Ş. (2015). İslam'da Bilginin Temelleri (Emr Kitabı). İstanbul: Küre.

Kürkçüoğlu, K. E. (ts.). Konuşmalar 2. İstanbul: Süleymaniye Kütüphanesi K. E. Kürkçüoğlu Bölümü, 100, T811.92.

Kürkçüoğlu, K. E. (ts.). Müteferrik Mektublartm. İstanbul: Süleymaniye Kütüphanesi K. E. Kürkçüoğlu Bölümü, 114, T816.

Muallim Nâcî (2009). Lügat-i Nâcî. Ahmet Kartal (Haz.). Ankara: Türk Dil Kurumu.

Nişanyan, S. (2018). Nişanyan Sözlük. İstanbul: Litera.

Özön, M. N. (1965). Osmanhca-Türkçe Sözlük. İstanbul: İnkılâp ve Aka Kitabevleri.

Pilten, Ş. (2013). Türk Dilinde Izdrrap Söz Bilgisi Bir Eş Anlamlılık İncelemesi. Ankara: Türk Dil Kurumu.

Redhouse, J. W. (1890). Turkish and English Lexicon. Constantinople.

Redhouse, J. W. (2009). Müntahabât-ı Lügat-i Osmâniyye. Recep Toparlı, Betül Eyövge Yılmaz, Yaşar Yılmaz (Haz.). Ankara: Türk Dil Kurumu.

Safa, P. (2000). Matmazel Noraliya’nın Koltuğu. İstanbul: Ötüken.

Steingass (1884). The Student's Arabic-English Dictionary. London.

Steingass (1892). A Comprehensive Persian-English Dictionary. London.

Sulak, S. (2016). Anlamdaş Kelimelerde Anlam ve Kullanış Farkları. Ankara: Gece.

Şu'ûrî, H. (2019). Lisânu 'l-Acem Ferheng-i Şu ûrî. Ozan Yılmaz (Haz.). İstanbul: Türkiye Yazma Eserler Kurumu Başkanlığı.

Şükûn, Z. (1984). Farsça-Türkçe Lûgat Gencinei Güftâr Ferhengi Ziya. İstanbul: Millî Eğitim Basımevi. TDK (2011). Türkçe Sözlük: Ankara: Türk Dil Kurumu.

Tebrîzî, M. H. (1251). Tibyân-i Nâfi der Terceme-yi Burhân-ı Kâtı. Ahmed Âsım (Trc.). İstanbul: Matba'a-yı Âmire.

Tekin, T. (1997). Eş anlamlılık ve kullanış. Türkoloji Eleştirileri. İstanbul: Simurg. 
Tietze, A. (2002). Tarihî ve Etimolojik Türkiye Türkçesi Lugati Cilt 1 A-E. İstanbul: Simurg.

Tietze, A. (2009). Tarihî ve Etimolojik Türkiye Türkçesi Lugati İkinci Cilt F-J. Wien: Verlag der Österreichischen Akademie der Wissenschaften.

Tietze, A. (2018). Tarihî ve Etimolojik Türkiye Türkçesi Lugati Beşinci Cilt M-N. Ankara: Türkiye Bilimler Akademisi.

Toven, M. B. (2015). Yeni Türkçe Lügat. Abdülkadir Hayber (Haz.). Ankara: Türk Dil Kurumu.

Ünaydın, R. E. (1985). Diyorlar ki. Ankara: Kültür ve Turizm Bakanlığı. 